
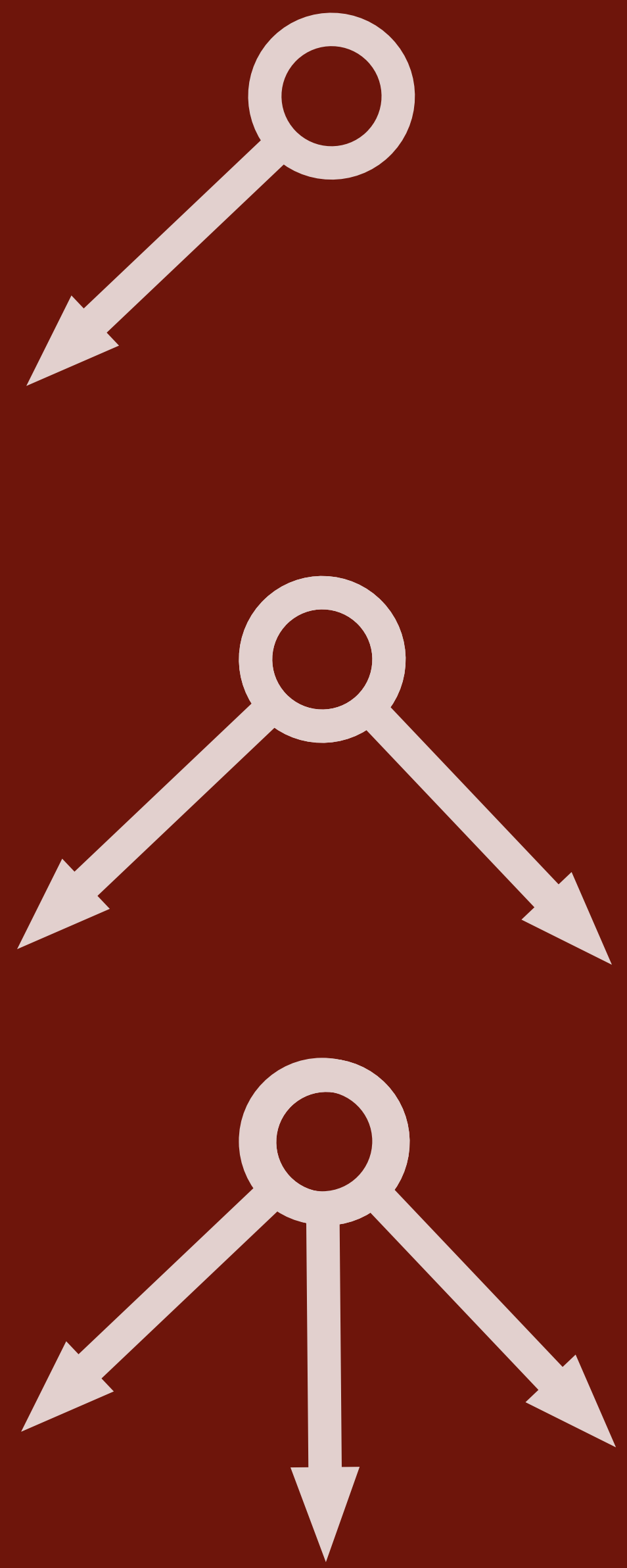


\title{
Technological Changes in the Neolithic Pottery Production of the South Iberian Peninsula: the Transition from the Middle to the Late Neolithic in Los Castillejos (Montefrío, Granada)
}

\author{
Jesús Gámiz Caro, Laura Vico Triguero, \\ Alberto Dorado Alejos \& Charles Bashore Acero
}

DOI:10.17234/9789531757799.7

Prehistory and Archaeology Department

University of Granada

Campus Universitario de Cartuja C.P.

ES-18011 Granada, Spain

jegamiz@ugr.es

Ivico@ugr.es

doradoalejos@ugr.es

charlesbashoreacero@gmail.com

In this paper, we present the analytical results of the vessels from Los Castillejos (Montefrio, Granada), attributed to the Middle and Late Neolithic periods (5000-4900 BC and 4200-3600 BC, respectively). The analytical corpus used in this study comes from techniques related to Earth Sciences (stereomicroscopy using a binocular microscope and X-ray diffraction). The results obtained have allowed us to differentiate the moments of the occupation of the site; the periods are separated by more than 700 years and present a marked difference in the ceramic production that allows us to identify a cultural change between the Middle and Late Neolithic.

\section{Introduction}

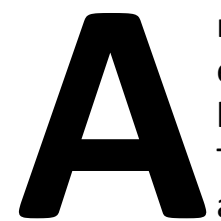
rchaeometry has been consolidated as an efficient approach in the study of archaeological material during the last decades. The use of analytical techniques applied to archaeological materials has allowed us to access a new dimension of knowledge that transcends the description of the object, giving it a full meaning and a unique role in the cultural characterization of the human groups that made and included it in daily activities, whatever their material nature might be, including these objects within the economic, social or ritual fields within the archeological construction (Shepard 1971; Howard 1982; Rice 1984; Steponatis 1984; Gibson and Woods 1997; Banning 2000; Spataro 2006; Peacock 2012; Klein and Philpotts 2013; Orton and Hughes 2013; Quinn 2013).

One of the research paths developed under the broad framework of analytical methodology has been devoted to the characterization of the manufacturing processes of artifacts, placing the producers themselves at the center of the production sequence. This allows us to relate the cultural context in which they are immersed as 
FIGURE 1. Geographic location of Los Castillejos (Montefrío, Granada).

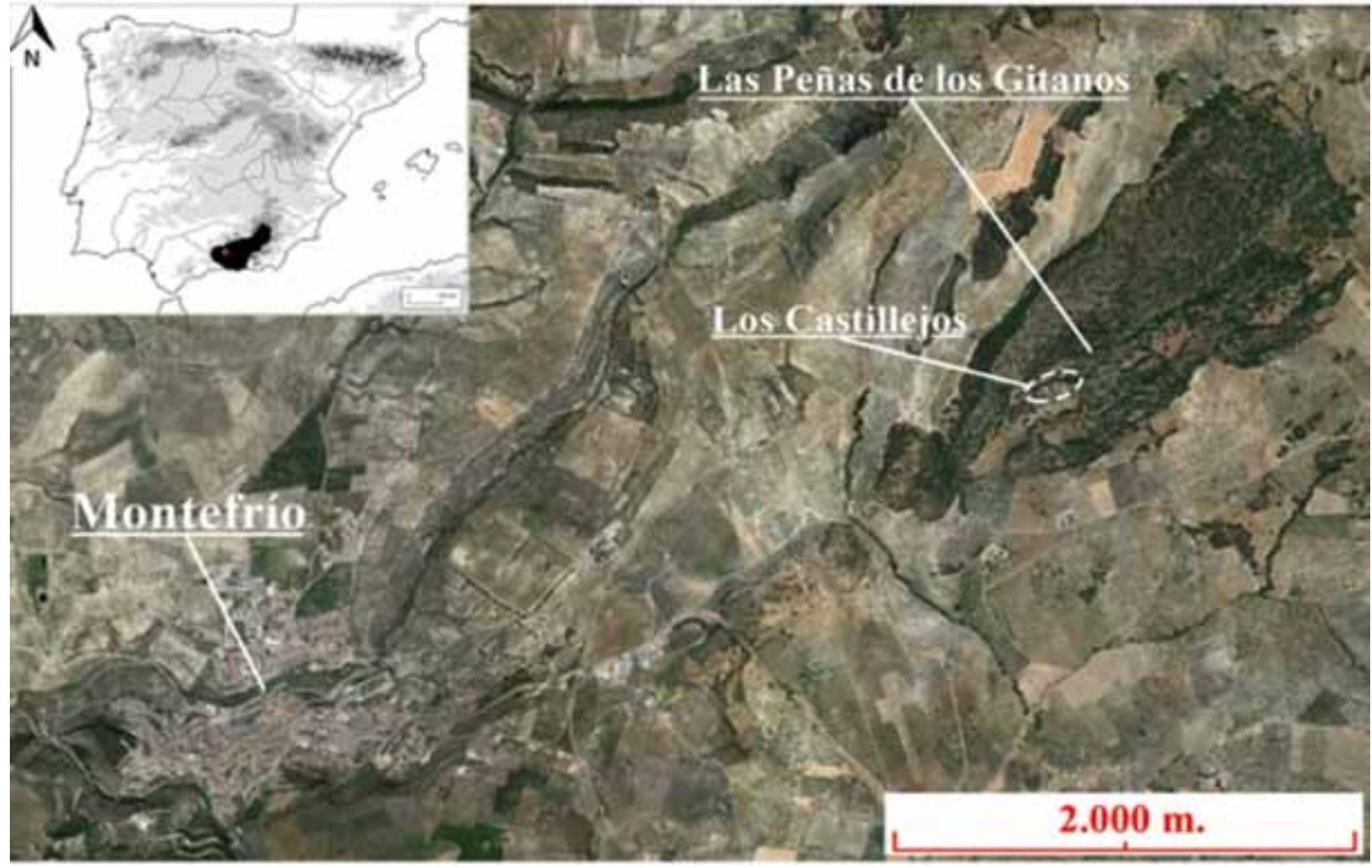

creators and beneficiaries of the object, with the result of the final product and its integration in the cultural system to which they belong.

Therefore, archaeometry has been the key through which we have been able to overcome the description of the material evidence, leading towards a more complex explanation, where the object does not dissociate from the subject, relating both to a specific activity within a concrete cultural system, not lacking in complexity, and its internal and external link at the social level (Albero 2011; Druc et al. 2013; García Roselló and Calvo 2013).

On the other hand, it must be borne in mind that artifacts recovered during archaeological interventions which have been carried out using an adequate excavation methodology can be located at a specific time and in a specific space according to their stratigraphic location. If we add this information to detailed analytical techniques, we can define more precisely the cultural context in which they were created, which inevitably leads to a better understanding of its aesthetic-functional value within the society that produced the object.

Based on this epistemological framework, in the present work we will analyze ceramic assemblages from the site of Los Castillejos (Montefrío, Granada), chrono-culturally framed between the Middle and the Recent Neolithic, a moment of transition in which a change in the cultural system is evident, which has been clearly evidenced in the technological characteristics of the ceramics under study.

\section{Los Castillejos (Montefrío, Granada)}

The settlement of Los Castillejos is located in the area known as Las Peñas de Los Gitanos (Fig. 1), 5 km east of the town of Montefrío in the province of Granada (Cámara et al. 2016).

This archaeological site is located geographically between the region of Los Montes and El Poniente Granadino, both framed in the System of the Subbética, formed by mountain ranges connected to each other by natural passages and fluvial courses, suitable for human occupation.

The singularity of this site is that it is an open-air, being the only one described in this region. The low agricultural potential of the site location has led to the unaltered preservation of the Neolithic sequence in the largest open-air village of the Iberian Peninsula (Cámara et al. 2016).

This non-alteration of the stratigraphic sequence has allowed the documentation of the chronological sequence, dated by means of radiocarbon dating of short life elements obtained during the development of the 
excavation campaigns carried in 1991-1994 (Ramos Cordero et al. 1997; Cámara et al. 2016). The result was a chronological framework composed of 23 dates analyzed in the Laboratory of the University of Uppsala, in the Beta Analytic Laboratory in Miami and in Laboratorium voor Algemene Naturkunde, Rijksuniversiteit of Groningen (Table 1). Of the first seven samples, six were sent to Beta Analytic and one to the Groningen laboratory. Of those sent to the first laboratory, three were analyzed by AMS and two were subjected to a double analysis, both by AMS and by conventional dating, showing significant differences in the results (Molina and Cámara 2004; Cámara et al. 2005). The stratigraphy was divided into 30 phases and sub-phases from the levels corresponding to the Ancient Advanced Neolithic to the Final Copper Age. The new data allowed to contextualize in more detail the issue regarding the transition between the Ancient and the Middle Neolithic and the beginning of the Recent
Neolithic (Cámara et al. 2005; 2016; Molina et al. 2017); we will focus this study on the last transition/phases. In this chronostratigraphic context, the existence of a temporary hiatus is detected, characterized on a material level by evidence of sedentary lifestyle and consolidation of agricultural practices materialized in the proliferation of silos as storage structures and the emergence of new constructive strategies, changes that take place in parallel to changes in the ceramic production which will be discussed in this paper.

\section{Objectives and Methodology}

The general objective of this research is to technologically characterize the ceramics from the phases prior to the hiatus (11a and $11 \mathrm{~b}$ between $5210-4940 \mathrm{cal} \mathrm{BC}$ ) and the subsequent ones (12 and 13 between 4240-3970 cal $\mathrm{BC})$, in order to determine the technical changes. Sec-

\begin{tabular}{|c|c|c|c|c|c|c|c|}
\hline PERIOD & PHASE & N. Sample & N. Lab. & DATE B.P. & DATE B.C. & I $\sigma$ cal BC & $2 \sigma \mathrm{cal} \mathrm{BC}$ \\
\hline \multirow{6}{*}{ NEOLITHIC } & I & MF614049 & Ua36215 & $6310 \pm 45$ & $4360 \pm 45$ & $5325-5220$ & $5470-5200$ \\
\hline & 2 & MF613836 & Ua36213 & $6120 \pm 40$ & $4170 \pm 40$ & $5210-4980$ & $5210-4950$ \\
\hline & \multirow{2}{*}{3} & MF6I3868 & Ua36214 & $6260 \pm 45$ & $4310 \pm 45$ & $5310-5210$ & $5330-5060$ \\
\hline & & $M F 612645$ & $B 135663$ & $6120 \pm 40$ & $4170 \pm 40$ & $5210-4980$ & $5210-4950$ \\
\hline & 5 & MF6I205I & Ua362II & $5400 \pm 45$ & $3450 \pm 45$ & $4335-4230$ & $4350-4060$ \\
\hline & 6 & MF613442 & $\mathrm{Ua362} / 2$ & $6240 \pm 45$ & $4290 \pm 45$ & $5310-5070$ & $5320-5050$ \\
\hline \multirow[b]{3}{*}{ MIDDLE } & \multirow{3}{*}{7} & \multirow{2}{*}{$M F 613428$} & B135664 & $6470 \pm 150$ & $4520 \pm 150$ & $5610-5300$ & $5700-5050$ \\
\hline & & & $B 145302$ & $6250 \pm 80$ & $4300 \pm 80$ & $5320-5070$ & $5380-4990$ \\
\hline & & MF6II678 & Ua36210 & $6100 \pm 45$ & $4150 \pm 45$ & $5200-4940$ & $5210-4900$ \\
\hline \multirow[t]{3}{*}{ NEOLITHIC } & 9 & MF610760 & Ua36209 & $6090 \pm 40$ & $4140 \pm 40$ & $5190-4940$ & $5210-4850$ \\
\hline & $10 a$ & MF610377 & Ua36208 & $6120 \pm 40$ & $4170 \pm 40$ & $5210-4980$ & $5210-4950$ \\
\hline & IIb & MF64868 & Ua36203 & $6115 \pm 40$ & $4165 \pm 40$ & $5210-4960$ & $5210-4940$ \\
\hline \multirow{2}{*}{$\begin{array}{c}\text { LATE } \\
\text { NEOLITHIC } \\
\end{array}$} & 13 & MF68020 & Ua36206 & $5265 \pm 45$ & $3315 \pm 45$ & $4230-3990$ & $4240-3970$ \\
\hline & 14 & MF68370 & Ua36207 & $4795 \pm 40$ & $2845 \pm 40$ & $3640-3520$ & $3660-3380$ \\
\hline FINAL NEOLITHIC & 15 & MF64337 & Ua36202 & $4980 \pm 35$ & $3130 \pm 35$ & $3790-3705$ & $3930-3650$ \\
\hline \multirow{2}{*}{$\begin{array}{c}\text { EARLY } \\
\text { COPPER AGE }\end{array}$} & $16 \mathrm{~b}$ & MF66158 & $B 135665$ & $4480 \pm 40$ & $2530 \pm 40$ & $3340-3090$ & $3350-3020$ \\
\hline & 17 & MF640I3 & Ua36201 & $4450 \pm 35$ & $2500 \pm 35$ & $3330-3020$ & $3340-2930$ \\
\hline \multirow{6}{*}{$\begin{array}{c}\text { LATE } \\
\text { COPPER AGE }\end{array}$} & \multirow{2}{*}{20} & MF62206 & Ua36200 & $3990 \pm 40$ & $2040 \pm 40$ & $2570-2470$ & $2620-2340$ \\
\hline & & MF6I45I & B135666 & $3770 \pm 70$ & $1820 \pm 70$ & $2300-2040$ & $2460-2020$ \\
\hline & 21 & MF65634 & Ua36204 & $3925 \pm 30$ & $1975 \pm 30$ & $2480-2340$ & $2490-2290$ \\
\hline & \multirow{3}{*}{22} & MF66883 & $B 135667$ & $3910 \pm 40$ & $1960 \pm 40$ & $2470-2340$ & $2550-2230$ \\
\hline & & \multirow{2}{*}{ MF61331 } & B135668 & $3640 \pm 120$ & $1690 \pm 120$ & $2200-1780$ & $2450-1650$ \\
\hline & & & B145303 & $3960 \pm 50$ & $2010 \pm 50$ & $2570-2340$ & $2580-2290$ \\
\hline \multirow{2}{*}{ FINAL COPPER AGE } & \multirow{2}{*}{$23 b$} & MF662 & GRN7287 & $3840 \pm 35$ & $1890 \pm 35$ & $2400-2200$ & $2460-2200$ \\
\hline & & MF6679I & Ua36205 & $3720 \pm 35$ & $1770 \pm 35$ & $2200-2030$ & $2280-2020$ \\
\hline
\end{tabular}

TABLE 1. Dates of $\mathrm{C} 14$ from Los Castillejos (Montefrío, Granada) (Cámara et al. 2016; Gámiz. 2018) 
ond, we will address the possible causes that gave rise to these changes, among which we must define those of functional origin (economic and social basis) and those of cultural origin (social and ritual/symbolic).

The ceramic selected for this study are 899 fragments of which 509 were analyzed by stereomicroscopy and 36 by X-ray diffraction. A Leica M80 binocular stereomicroscope with magnifications up to $60 x$, with an EC3 high definition camera ( $0.5 x$ objective), was used for the analysis. The stereomicroscope is located in the Antonio Arribas Palau Archeometry Laboratory of the University of Granada. The analyzed fragments were cut in order to have a clean section of the interior of the ceramics; after, we describe two areas of the section, following a descriptive routine based on several works already published (Gámiz et al. 2013; Druc and Chavez 2014; Gámiz 2018). The areas of description and the variables observed were: a) surface of the fragment, with a description of the surface treatment, decorative techniques, technological marks, systemic and post-depositional alterations, as well as the color of the external and internal surfaces; $b$ ) description of the internal section of the fragment which takes into account the compactness of the paste, the color of the matrix, nature, size, distribution, orientation and proportion of the non-plastic.

The optical observation was complemented by X-ray diffraction, performed by powdering the sample $(10 \mu)$ and analyzing it in a BRUKER D8 ADVANCE diffractometer with $\mathrm{Cu}$ radiation (sealed tube) and LINXEYE detector under a measurement parameter of 2 " per scanning step, in an increment of 0.00393766 with limit of 2 theta at start in 3 and stop in 70.0108, at a power of $40 \mathrm{Kw}$ and $40 \mathrm{~mA}$. The resulting diffractograms were read using the Software XPowder 12 v.00.27, and the DifData database and PDF2. By XRD we were able to identify and quantify the minerals present in the sediments used in the ceramic production.

The application of these analytical techniques brings us closer to the characterization of the different stages of manufacture. We will talk about the production sequence, a concept that is inspired by the, though not always correctly used, chaine opératoire. We understand the process of making an object by studying its production sequence, which, through its characterization, allows us to suggest its functionality, without addressing other aspects such as its life and disuse (Rye 1994). In this way, we determine the ceramic production sequence on the basis of the following phases: raw material collection, clay treatment, modeling, surface treatment, drying and firing.

\section{Discussion}

The study of the ceramics from phases $11 \mathrm{a}$ and $11 \mathrm{~b}$ (between 5210-4940 Cal BC) (Table 1), during the last moments of the Middle Neolithic, show us a series of technological features that are the result of the continuity of a pottery tradition, which has remained virtually unchanged since the Early Advanced Neolithic (Gámiz 2018). These collection areas were defined by comparison of the XRD results obtained from the ceramics that have been studied and the results obtained from soil samples. Thus, we observe how there is a predilection for those areas where the sediments are characterized by a high content of quartz, with a particle size below 2 $\mathrm{mm}$ and with an estimated saturation above $20 \%$. The high sphericity and the variability of the minerals place the sediment extraction in detrital areas and with a high degree of erosion, being the fluvial beds the most feasible areas for the collection of sediments. Three water courses are present next to the settlement. This data, together with the verification of the results obtained by XRD among the sediment samples taken from the surrounding environment, the mineralogical characterization offered by the Geological Survey of Spain (IGME) in the cartography of Alcalá la Real and Montefrío (IGME 1985), and the XRD results of the analyzed ceramics, allows us to affirm that the origin of the material used in the manufacture of the ceramics is local (Gámiz 2018), with the exception of the pigments used for engobes, such as those used in the characteristic Almagra ceramics, which do not pose a series of new issues. The first reason is due to the detection of mercury in these pigments by means of Scanning Electron Microscope (SEM), an element that is directly related to cinnabar. Still to be confirmed through a study in progress, the origin of this mineral is found far from the area under study, in very localized deposits in the southern areas of the Peninsula, such as the outcrops of Cástaras and Tímor (Granada), Bayeque and Tíjola (Almería) and the larger quantity in Almadén (Ciudad Real) (AA.VV. 1986; Hunt and Hurtado 2009; Tsantini et al. 2018). This would indicate an exchange of raw material over long distances.

In the preparation phase of the raw material, we distinguish several actions. The first one, the alteration of the sediment by means of manual purification, where the non-plastic inclusions that may hinder the mixing of the clay are extracted, such as coarse clasts and elements of plant origin such as small branches or stems. After this action, we detect the opposite process, that is, the adhesion of non-plastic inclusions that are added as temper to subtract clay plasticity (Fanlo and Pérez 2011; Clop 2012, Cubas 2012). The addition of temper was a fre- 
FIGURE 2. Ceramics of the Middle Neolithic of Los Castillejos with different types of temper:

A) chamotte,

B) mineral,

C) vegetal.

(Scales: $5 \mathrm{~mm}$ )
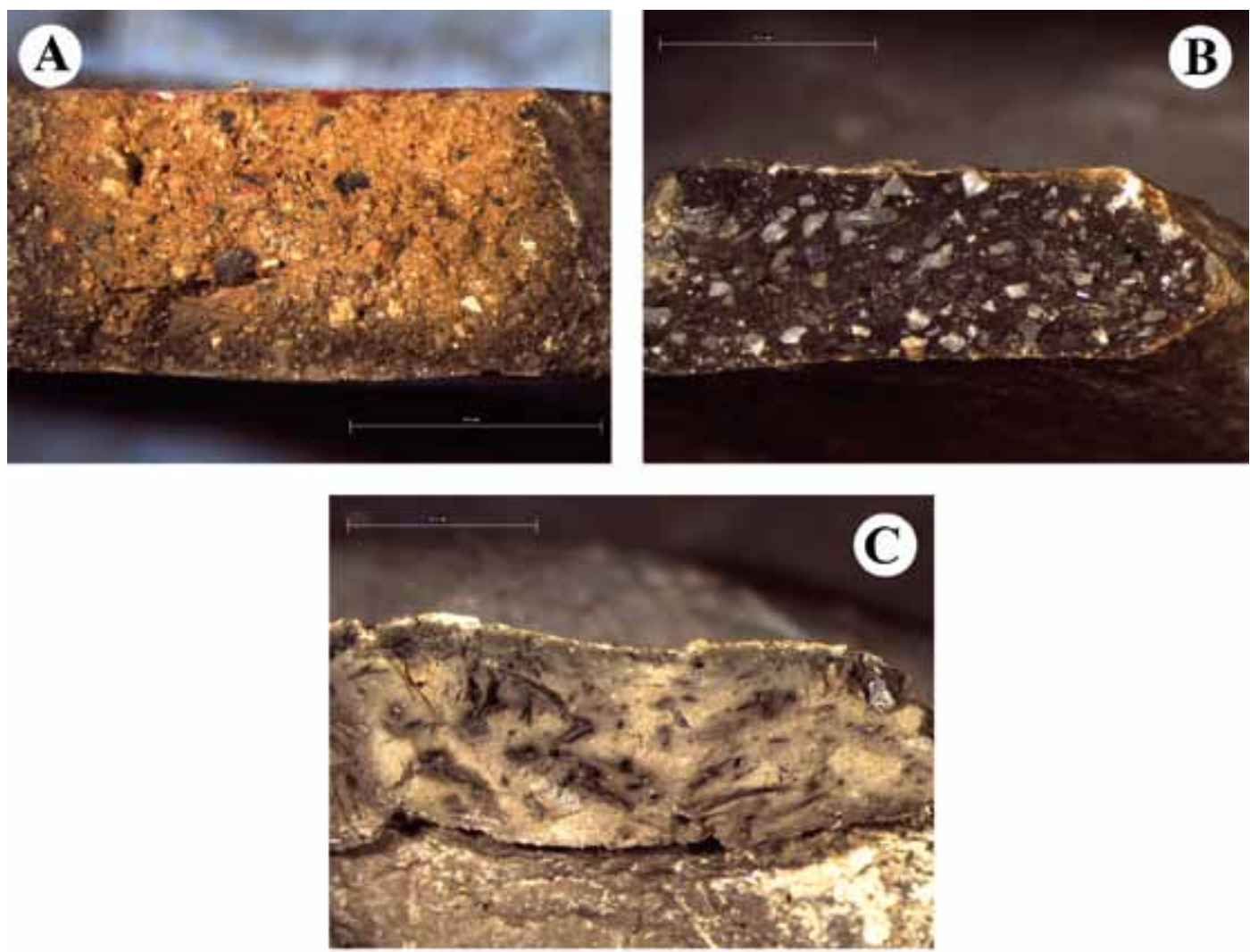

quent action that isalso identified during Early Neolithic in other geographical areas such as Valencia or Cataluña (Clop 2012), and materializes in the detection of chamotte in ceramic paste, systematizing the practice of adding crushed ore since the last moments of the Middle Neolithic onwards (Fig. 2).

Among the studied ceramic, we observed the presence of minerals with a high degree of angularity, with very similar sizes (between 1 and $2 \mathrm{~mm}$ ) and in a high proportion between grains considered to be of the same mineral type. These observations contrast with those ceramics with very rounded grains and with greater mineral diversity, characteristic of sediments collected from or near rivers as has been previously explained. Through XRD we were able to verify that the calcite or quartz levels exceed in most cases those of other mineral phases, a phenomenon that coincides in those ceramics with the granulometric characteristics to which we refer (Fig. 3).

The presence of these minerals gives the final product a greater mechanical and thermal resistance, in addition to subtracting plasticity from the clay in order to facilitate its modeling, the drying of the piece and to reduce firing failures during the same (García Roselló and Calvo 2006). On the other hand, the existence of ceramic pastes with a high content of pores and grooves suggests the addi- tion of plant matter acting as a temper, especially for the production of ceramics related to the conservation of food and provisions, since these pores generate a cool environment inside the container (Ortega et al. 2005). Finally, this phase of production will conclude with the kneading of the paste. The greater or lesser dedication to kneading, the concentration and size of the temper and the volume of water contained, are characteristics that will determine the compaction of the paste (Rice 1987; Rye 1994; Gibson and Woods 1997; Orton and Hughes 2013). The compaction will affect other phases of the production sequence such as drying since ceramics with optimal compacting paste avoid the appearance of cracks and defects in the surfaces of the vessels, which in turn elevates the possibilities of success during firing. On the other hand, these ceramics are likely to contain excess water, which causes a sudden contraction of the walls during drying and firing, resulting in vessels with structural defects or failed firing. The end of the Middle Neolithic culminates in a consistent trend with a domain over ceramics with a high degree of compaction, as we have been able to see in the Ancient Neolithic as well, with which we can confirm the survival of techniques in ceramic manufacturing, and what we interpret as continuation within the ceramic production tradition. However, there is a minority of fragments that show poor 


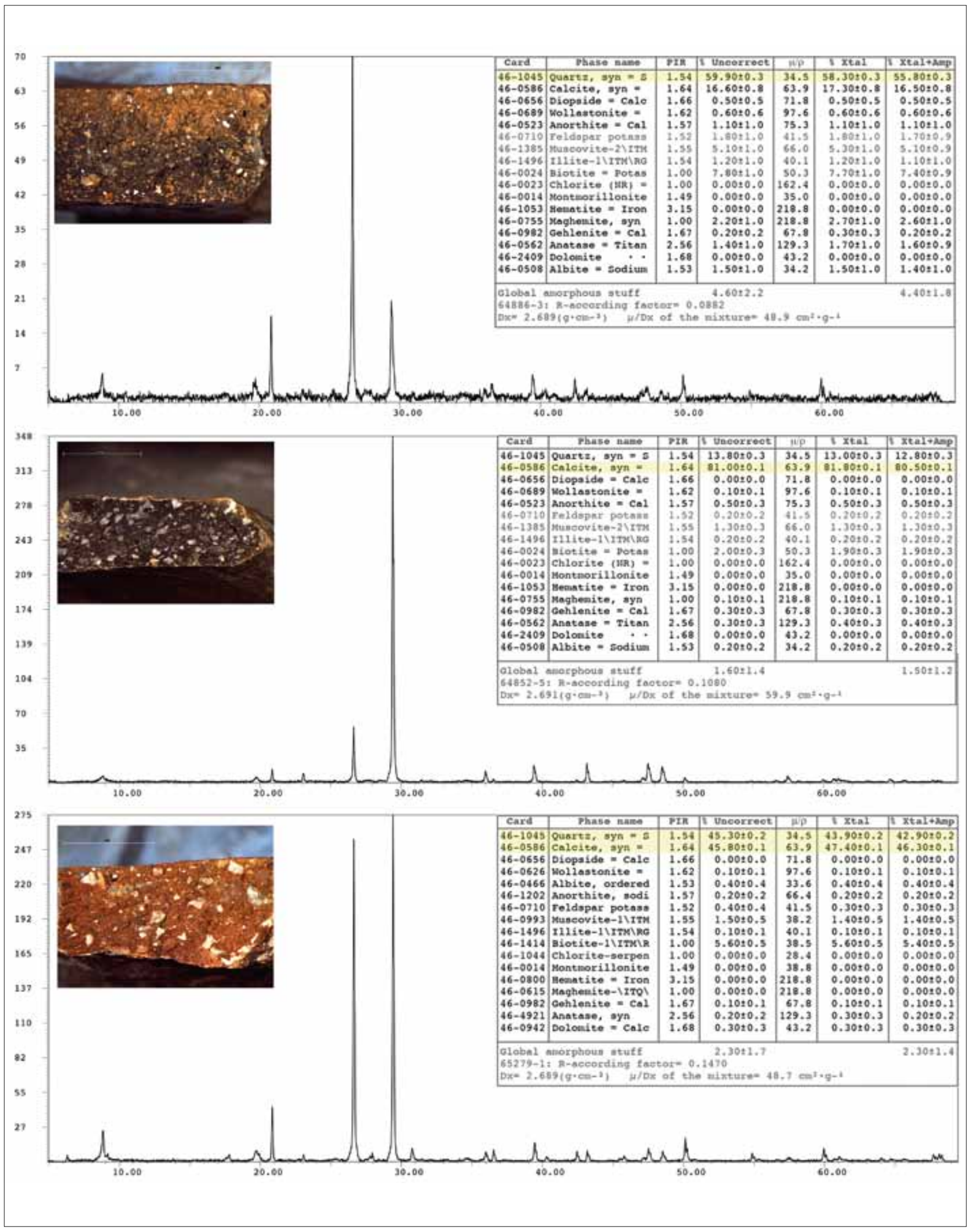

FIGURE 3. Ceramic diffractograms from the Middle Neolithic of Los Castillejos (Montefrío, Granada). Above: sample with high quartz content, Center: sample with high calcite content, Below: sample with equality between calcite and quartz. 
FIGURE 4. Ceramic sections from the Middle Neolithic of Los Castillejos

(Montefrío, Granada):

A) compact ceramic and

B) not very compact ceramic.

(Scales: $5 \mathrm{~mm}$ )
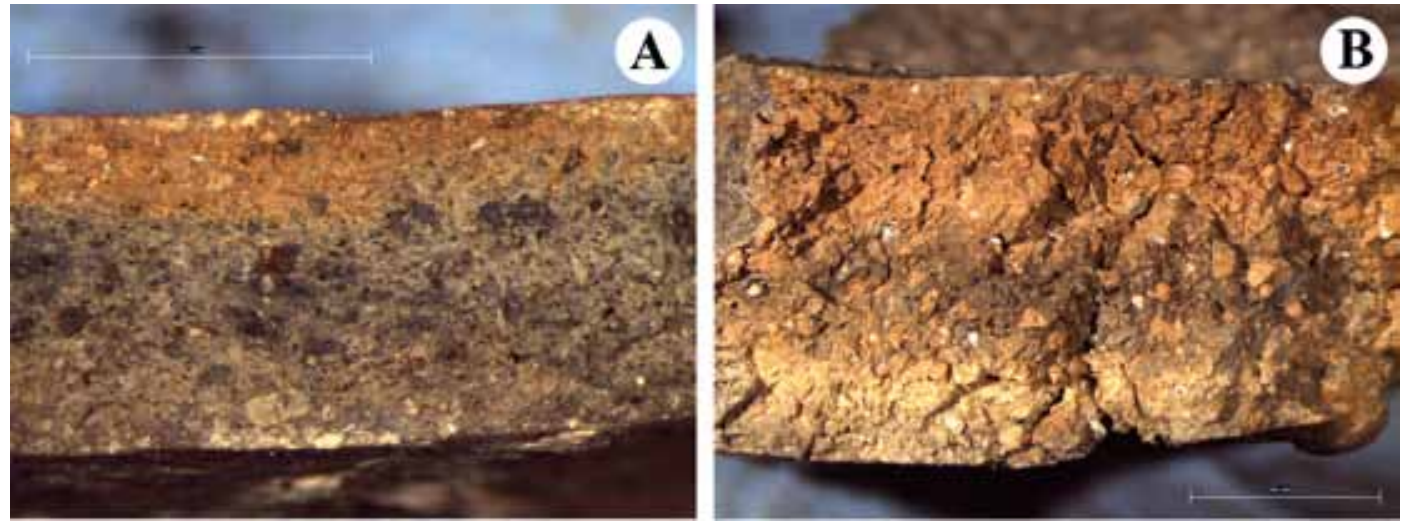

compaction (Fig. 4), the result of loose or insufficient kneading work. These types of productions are related either to circumstantial elaborations or to learning processes (Bagwell 2001; Kamp 2010).

Regading the modeling techniques, traces that clearly indicate the techniques used were not detected. However, after elaborating the typology corresponding to the ceramics object of study (Gámiz 2018), we deduce that techniques such as hollowing, mold and overlap of rolls or plates, also defined as rollos de columbí (coils), must have been used. Therefore, we attribute the technique of hollowing to small containers such as bowls, and the use of the molds for the base, which are completed with the superposition of rolls or coils, a technique which is easier to detect in composite forms of two bodies or in the elevation of ceramic necks.

On the other hand, in the surface treatments we distinguish two features: on the one hand the exterior treatment in itself, and on the other the decoration. Decoration will be an aspect that we will ignore in this work since the entity of the description deserves a separate study. Focusing therefore on the surface treatment, smoothing and burnishing were identified. In the first case, it is only intended to achieve a regularization of the surface, achieved presumably without the use of tools simply by hand. On the other hand, burnishing becomes the most used technique, since greater uniformity than in the previous case is achieved, in addition to providing the piece with a greater aesthetic degree and conferring impermeability and non-stick property to the pot. This technique requires the use of tools or intermediaries with a rough surface that allows the polishing of the surfaces, such as stone or animal skins.

The drying phase, in most cases, can be determined optimal. This inference is obtained through the study of the pastes, which present a uniformity without striations which indicates an absence of estimable quantities of water before firing. From this description are excluded those ceramics to the learning process that have been previously mentioned.

Finally, different traces identified in the studied fragments allow us to determine that firing action was carried out without the use of any kind of structure and therefore temperature control and firing time. The evidence of this are the chromatic variability of the fragments as well as the irregularity of these colors in different areas or shards belonging to the same ceramic. In the same way, if we compare the sections of the different fragments we can observe how some of them indicate firing in an oxidizing atmosphere and others in a reducing atmosphere. The most common colour among the studied fragments are dark core sections with beige or reddish edges. This variability is related to the position of the ceramic inside the fire and its greater or lesser proximity to the source of heat. With these characteristics, we deduce that the combustion that the combustion was carried out using holes dug in the earth where the ceramics would have been placed along with the fuel. It was possible to establish an approximation of the firing temperatures by XRD. The presence of calcite in many fragments, together with the appearance of gehlenite (Fig. 5) allows us to determine a fiering temperature between 500 and 800 @C (Capel et al. 1979: Ortega et al. 2005).

Levels 12 and 13 belong to what we call Late Neolithic (4240-3970 Cal BC). This new period takes place after a long and widely documented temporal hiatus of more than 700 years in Los Castillejos (Cámara et al. 2016; Molina et al. 2017) (Table 1). Among the ceramic objects that belong to this phase, a series of changes that break with the pottery tradition described for phases 11a and $11 \mathrm{~b}$ have been documented. On the one hand, we will highlight the irruption of new forms that were not present in the previous period, as is the case of casseroles 


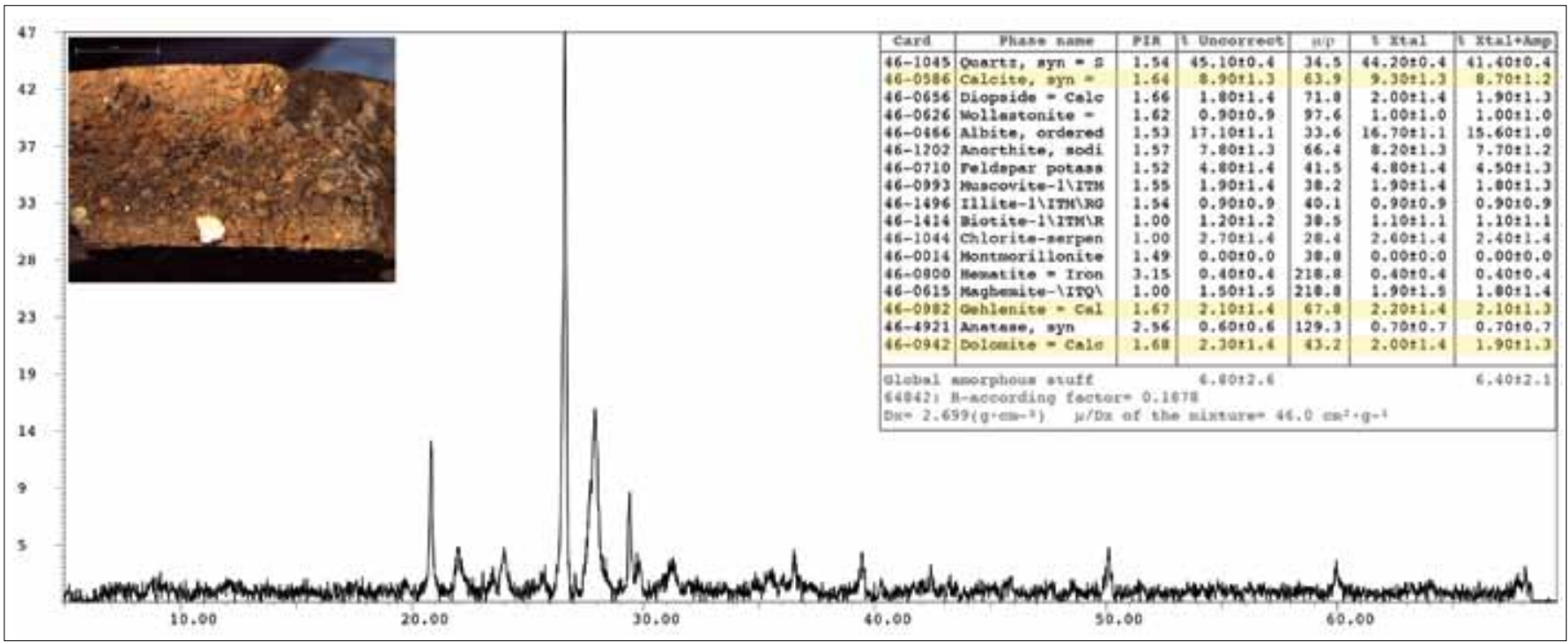

FIGURE 5. Diffractogram of fragment beloning to the Middle Neolithic phase of Los Castillejos (Montefrío, Granada) showing the presence of calcium carbonate in low proportions and gehlenite.

(Fig. 6). The fragments and forms associated with these new types at a quantitative level are far above the other types of the forms; but it is also that, at a qualitative level, they present characteristics radically different from previous productions. The main technological change lies within the systematic addition of temper mineral to the ceramic paste, mainly calcium carbonate (calcite and dolomite) (Fig. 7). The properties of these minerals, previously mentioned (refractory and flux), predispose new productions wih functions related to food preparation and consumption.

The analyzed fragments show an absolute predominance of ceramics with a high degree of compaction. This evidence is a consequence of two factors: on the one hand, the high presence of temper, which increases the chances of success during the drying and firing stages; on the other hand, the high compaction denotes a continuous work in the kneading of the clay, now associating all the ceramic production to expert hands.

Regarding the modeling techniques, the techniques identified for the previous period will be repeated, with the exception that the most common method would now be the use of molds for the base and then raising the ceramic by using coils, mainly for elaboration of the pots, composed of two bodies, which is also the most common ceramic production during this phase. C e ramic decoration during this period is practically nonexistent and in the case of the casseroles is absent. However, burnishing is conferred as the external treatment technique par excellence. This fact will be related again with the budgeted functionality of these forms, since the characteristics of burnishing makes the ceramic suitable for the processing and consumption of food.

Finally, in the drying and firing phases, there are no differences with regards to the previous period. The features identified in the ceramic productions during this phase are the same as there are no identifiable changes from the point of view of innovation for these stages of the production sequence.

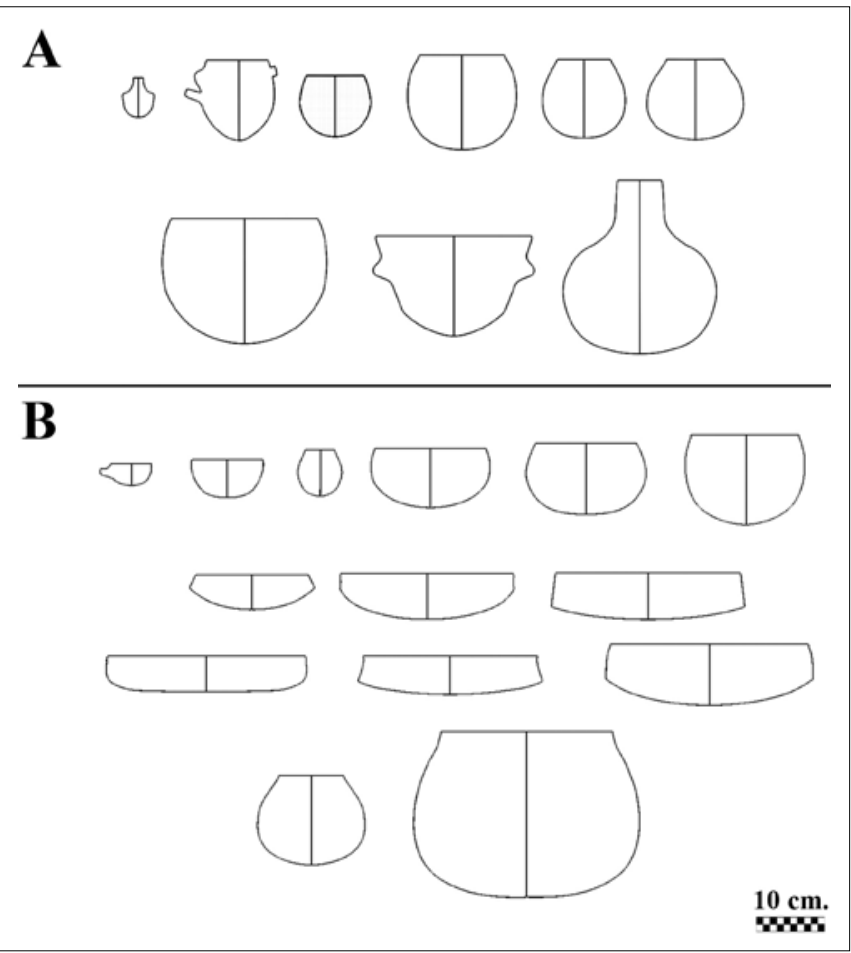

FIGURE 6. Ceramic types of Los Castillejos (Montefrío, Granada): A) Middle Neolithic, B) Late Neolithic. 


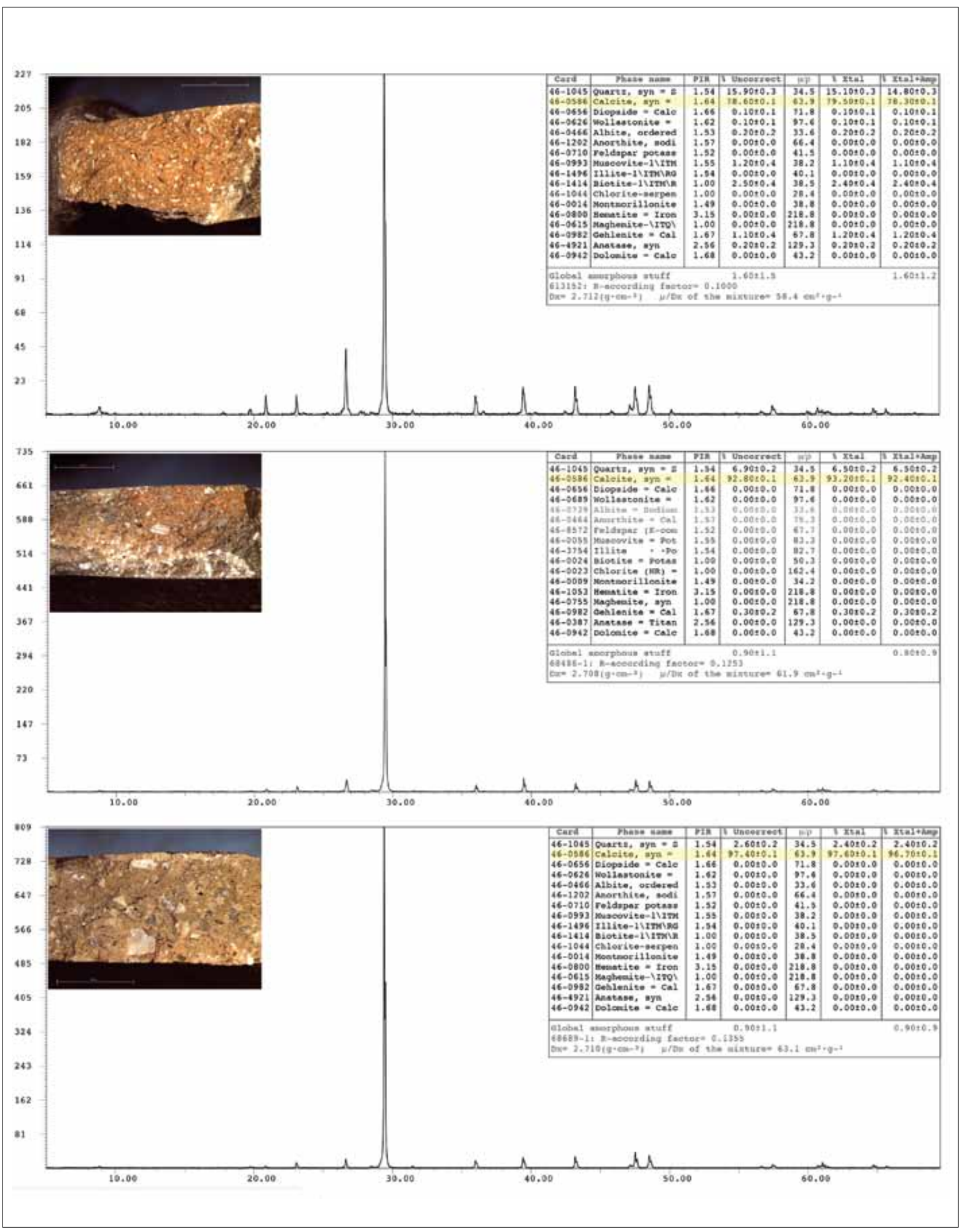

FIGURE 7. Ceramics difractograms of the Late Neolithic of Los Castillejos (Montefrío, Granada) showing the high content of calcite added as temper. 


\section{Conclusions}

The data obtained from the study presented here show us a change in the pottery production between the phases prior to the temporary hiatus and the one carried out after it. The changes referenced in this work concern the typology and the technological characterization of ceramic production.

On these bases, we can affirm that pottery tradition between one period and the other change substantially due to the fact that these changes take place during a chronological hiatus of more than 700 , and thus these must have been originated by different human groups, with a different cultural system, also evidenced by deeper economic and social changes, which we describe below.

Regarding the economic aspects, it has been possible to verify through carpological characterization studies (Rovira 2007; Cámara et al. 2016) that cereal production suffers a considerable increase. This increases in agricultural production are also related to the proliferation of silo-type structures and the increase in volumes of ceramic forms related to storage such as pots or jars (Gámiz 2018). In the same way, animal husbandry also intensifies, specializing in the stockbreeding of cattle, sheep/ goats, bovine and porcine (Riquelme 1996; Camera et al. 2016).

The result of this increase in agricultural exploitation linked with a specialization in the breeding and cultivation of certain species, which leads, in consequence, to a demographic increase evidenced in the urban modifications documented in the settlement during the beginning of the Late Neolithic (4200-3600 BC). The material evidence of this situation is materialized in the proliferation of silos, the increase in size and complexity of the habitat structures and an expansion of the occupation area of the Los Castillejos (Cámara et al. 2016).

The presence of a hiatus in the chronostratigraphic sequence of more than 700 years (Molina et al. 2017), makes us think that during this phase the settlement is uninhabited for reasons still unknown. However, the documentation from levels 12 and 13 of evidence corresponding to a human group with fully defined cultural characteristics and different from those identified in the levels $11 \mathrm{a}$ and $11 \mathrm{~b}$, allow us to affirm that the enclave is reoccupied. In this sense, we will relate the settlement of Los Castillejos during the Late Neolithic (4200-3600 $\mathrm{BC})$ with a phenomenon regarding population movement from the lower Guadalquivir documented in settlements near the settlement case of this study, such as those identified in Cordoba's countryside (Nocete 1989) or the Polideportivo de Martos (Jaén) (Lizcano et al. 1997; Cámara et al. 2008). The new configuration of the economic base, the changes in the social structure and the changes in the belief system, have served to consider this Neolith phase as the genesis of the factors that will configure the defining characteristics of the Chalcolithic, where the first clear evidence of a social structure based on access and differential control of the modes of production and economic surplus will be documented.

\section{Final Note}

This work has been carried out within the framework of the research group Hum-274 GEPRAN, belonging to the Department of Prehistory and Archaeology of the University of Granada. On the other hand, we would like to thank the active participation in the direction of this work and the invaluable help of Fernando Molina González and Juan Antonio Cámara Serrano. 


\section{References}

AA.VV. 1986. Libro blanco de la minería andaluza, Consejería de Economía y Fomento, Junta de Andalucía, Sevilla.

Albero Santacreu, D. J. 2011. Caracterización tecnológica, social y adaptación funcional de cerámicas prehistóricas en el oeste y sureste de Mallorca (1700-50 BC), Departamento de Prehistoria y Arqueología. Universidad de Granada. Facultad de Filosofía y Letras, Granada.

Bagwell, E. 2001. Ceramic Form and Skill: Attemptig to Identify Child Producers at Pecos, Nex Mexico, In: K. A. Kamp (ed.), Children in the Prehistoric Puebloan Southwest, University of Utah Press, Salt Lake City, 90-107.

Banning, E. 2000. The Archaeologist's Laboratory: The Analysis of Archaeological Data, Kluwer Academic/Plenum Publishers, New York.

Cámara Serrano J. A., Molina González, F. and Afonso Marrero, J. A. 2005. La cronología absoluta de Los Castillejos en Las Peñas de los Gitanos (Montefrío, Granada), Actas del III Congreso del Neolítico en la Península Ibérica, Santander, 5-8 de octubre de 2003, 841-852.

Cámara Serrano, J. A., Lizcano Prestel, R., Pérez Bareas, C. and Gómez Toro, E. 2008. Apropiación, sacrificio, consumo y exhibición ritual de los animales en el Polideportivo de Martos. Sus implicaciones en los orígenes de la desigualdad social, Cuadernos de Prehistoria Universidad de Granada $18,55-90$.

Cámara Serrano, J. A., Afonso Marrero, J. A. and Molina Gónzalez, F. 2016. La ocupación de La Peña de los Gitanos (Montefrío, Granada) desde le Neolítico al mundo romano. Asentamiento y ritual funerario, In: R. J. P. Megias (ed.), Arqueología e historia de un paisaje singular: Las Peñas de los Gitanos (Montefrío-Granada), Ministerio de Cultura, Montefrío, 18-121.

Capel Martínez, J., Linares González, J. and Huertas García, F. 1979. Métodos analíticos aplicados a cerámicas de la Edad del Bronce, Cuadernos de Prehistoria Universidad de Granada 4,345-360.

Clop Garcia, X. 2012. Extensión, cambios y perduración en las "formas de hacer": la producción cerámica y el uso de desgrasantes añadidos, In: Xarxes al Neolític: Circulació $i$ intercanvi de matèries, productes i idees a la Mediterrània occidental (VII-III mil lenni aC), Gavà/Bellaterra, 2-4 de febrero de 2011, 369-374.

Cubas, M. 2012. La utilización de desgrasantes en las manufacturas cerámicas del Vo milenio Cal BC en el Norte de la Península Ibérica, In: Xarxes al Neolític, Gavà/Bellaterra, 2-4 de febrero de 2011, 375-382.

Druc, I. C., Inokuchi, K. and Shen, Z. 2013. Análisis de arcillas y material comparativo por medio de difracción de rayos $\mathrm{X}$ y petrografía para Kuntur Wasi, Cajamarca, Perú, Arqueología y Sociedad 26, 91-110.
Druc, I. C. and Chavez, I. 2014. Pastas cerámicas en lupa digital: Componentes, Texturas y Tecnología, Deep University Press. Wisconsin.

Fanlo Loras, J. and Pérez Lambán, F. 2011. Consecuencias de la incorporación de carbonato cálcico en el material cerámico, Estrat Crític 5-3, 61-68.

Gámiz Caro, J. 2018. La cerámica neolítica de Los Castillejos (Montefrío. Granada). Estudio tipológico, decorativo y tecnológico, Universidad de Granada, Granada.

Gámiz Caro, J., Dorado Alejos, A. and Cabadas Báez, H. V. 2013. Análisis de cerámica prehistórica con estereomicroscopía: una guía revisada sobre la descripción de las fases de producción, Cuadernos de Prehistoria y Arqueología de la Universidad de Granada 23, 365-385.

García Roselló, J. and Calvo Trias, M. 2006. Análisis de las evidencias macroscópicas de cocción en la cerámica prehistórica: una propuesta para su estudio, Mayurqa 31, 83112.

García Roselló, J. and Calvo Trias, M. 2013. Making Pots. El modelado de la cerámica a mano y su potencial interpretativo. BAR International Series 2540, Archaeopress, Oxford.

Gibson, A. and Woods, A. 1997. Prehistoric pottery for the archaeologist, Leincester University Press, London.

Howard, H. 1982. Clay and the archaeologist, In: I. Freestone, C. Johns and T. Potter (eds.), Current research in ceramics: Thin-section studies, British Museum Occasional Paper 32, 145-158.

Hunt Ortiz, M. A. and Hurtado Pérez, V. M. 2009. Pigmentos de sulfuro de mercurio -cinabrio- en contextos funerarios de época calcolítica en el sur de la Península Ibérica: investigaciones sobre el uso, depósitos minerales explotados y redes de distribución a través de la caracterización composicional e isotopía, In: VIII Congreso Ibérico de Arqueometría, 123-132.

IGME. 1985-87. Mapa geológico de España a escala 1/50.000, HOJA 1008/990, 18-4/18/40. Montefrío y Alcalá la Real, Instituto Geominero de España, Madrid.

Klein, C. and Philpotts, A. 2013. Earth Materials. Introduction to Mineralogy and Petrology, Cambridge, Cambridge University Press.

Kamp, K. A. 2010. Entre el trabajo y el juego: perspectivas sobre la infancia en el suroeste norteamericano, Complutum 21 (2), 103-120.

Lizcano, R., Cámara, J. A., Riquelme, J. A., Cañabate, Ma․ L., Sánchez, A. and Afonso, J. A. 1997. El polideportivo de Martos. Producción económica y símbolos de cohesión en un asentamiento del Neolítico Final en las Campiñas del Alto Guadalquivir, Cuadernos de Prehistoria Universidad de Granada 16-17, 5-101. 
Molina González, F. and Cámara Serrano, J. A. 2004. El megalitismo en el sureste de la Península Ibérica. Ideología y control territorial, Mainake 26, pp. 139-163.

Molina González, F., Cámara Serrano, J. A., Afonso Marrero, J. A., Gámiz Caro, J., Capel Martínez, J. and Martínez Fernández, G. 2017. Hiatus in an archaeological multilevel site: Los Castillejos in Las Peñas de los Gitanos (Montefrío, Granada), In: M. Cupitò, M. Vidale and A. Angelini (ed.), Beyond Limits. Studi in onore di Giovanni Leonardi, Padova University Press, Padova, 91-100.

Nocete Calvo, F. 1989. El espacio de la coerción. La transición al Estado en las Campiñas del Alto Guadalquivir (España). 3000-1500 A.C., British Archaeological Reports, International Series 492, Oxford.

Ortega, A., Zuluaga, M. C., Alonso, A. and Olaetxea, C. 2005. El estudio arqueométrico de las producciones cerámicas, MUNIBE (Antropologia-Arkeologia) 57, 365-388.

Orton, C. and Hughes, M. 2013. Pottery in Archaeology, Cambridge University Press, Cambridge.

Ramos Cordero, U., Afonso Marrero, J. A., Cámara Serrano, J. A., Molina González, F. and Moreno Quero, M. 1997. Trabajos de acondicionamiento y estudio científico en el yacimiento de Los Castillejos de Las Peñas de los Gitanos (Montefrío, Granada), Anuario Arqueológico de Andalucía 1993:III, 265-271.

Peacock, D. P. S. 2012. The scientific analysis of ancient ceramics: A review, World Archaeology 1 (3), Analysis, 375389.

Quinn, P. S. 2013. Ceramic Petrography. The interpretation of archaeological pottery and related artefacts in thin section, Archeopress. Oxford.

Rice, P. M. 1984. The archaeological study of specialized pottery production: Some aspects of method and theory, In: P. M. Rice (ed.), Pots and Potters: Current Approaches in Ceramic Archaeology, Institute of Archaeology, University of California, Los Angeles, 45-54.
Rice, P. M. 1987. Pottery analysis: A Sourcebook, The University of Chicago Press, Chicago.

Riquelme Cantal, J. A. 1996. Contribución al Estudio Arqueofaunístico durante el Neolítico y la Edad del Cobre en las Cordilleras Béticas: el Yacimiento Arqueológico de Los Castillejos en Las Peñas de los Gitanos, Montefrío (Granada), Universidad de Granada, Granada.

Rovira Buendía, N. 2007. Agricultura y gestión de los recursos vegetales en el sureste de la Península Ibérica durante la Prehistoria Reciente, Universitat Pompeu Fabra, Barcelona.

Rye, O. S. 1994. Pottery technology: Principles and recostruction, Taraxacum Manuals on Archaeology, Washington D. C.

Shepard, A. O. 1971. Ceramics for the archaeologist, Carnegie Institution of Washington, Washington, D. C.

Spataro, M. 2006. Pottery typology versus technological choices: An early Neolithic case study from Banat (Romania), Analele Banatului 14 (1), 63-78.

Steponatis, V. P. 1984. Technological studies of prehistoric pottery of Alabama: Physical properties and vessel function, In: S. E. Van der Leeuw and A. C. Pritchard (eds.), The many dimension of pottery: Ceramics in archaeology and anthropology, University of Amsterdam, Amsterdam, 79128.

Tsantini, E., Minami, T., Takahashi, K. and Cau Ontiveros, M. A. 2018. Analysis of sulphur isotopes to identify the origin of cinnabar in the Roman wall paintings from Badalona (Spain), Journal of Archaeological Science 18, 300-307. 